\title{
PREZENTACJE
}

Jerzy Potoczny

(Lublin)

\section{Jubileusz profesora Andrzeja Meissnera}

W 2007 r. prof. Andrzej Meissner ukończył 70 lat, z tego 45 przepracował w zawodzie nauczyciela akademickiego. Istnieje więc okazja do zaprezentowania sylwetki Jubilata i jego najważniejszych dokonań naukowych.

Prof. A. Meissner swoją formację naukową kształtował na studiach pedagogicznych, które odbył na Wydziale Filozoficzno-Historycznym Uniwersytetu Jagiellońskiego. Specjalizował się w dziedzinie historii wychowania pod kierunkiem naukowym prof. Jana Hulewicza i prof. Kamilli Mrozowskiej. Pod kierunkiem prof. K. Mrozowskiej napisał i obronił pracę magisterską pt. Stosunek zgromadzeń zakonnych (benedyktynów, cystersów i bartoszków) do Komisji Edukacji Narodowej.

W latach 1961-1971 pracował jako nauczyciel przedmiotów pedagogicznych w Studium Nauczycielskim w Krośnie. W okresie tym zdecydowanie ukierunkował i skonkretyzował własne zainteresowania badawcze na zagadnienia historyczno-oświatowe i pedeutologiczne, a przede wszystkim na problematykę kształcenia nauczycieli. Równocześnie z pracą zawodową łączył działania badawcze. Uczęszczał na seminarium doktoranckie w Zakładzie Historii Nauki i Kultury UJ prowadzone przez prof. Jana Hulewicza. Swój wysiłek naukowy uwieńczył w 1971 r. doktoratem nauk humanistycznych w zakresie pedagogiki. Była to rozprawa pt. Zakłady kształcenia nauczycieli w Krośnie w latach 1895-1962, która powstała pod kierunkiem naukowym K. Mrozowskiej, profesora Uniwersytetu Jagiellońskiego.

W latach 70. podjął intensywne studia nad oświatą okupacyjną i odbudową szkolnictwa po II wojnie światowej na terenie południowo-wschodniej Polski. Wieloletnie badania w tej dziedzinie zaowocowały pracą habilitacyjną, pt. Odbudowa szkolnictwa ogólnokształcacego w województwie rzeszowskim w latach 1944-1949 (Rzeszów 1982), którą w roku 1983 obronił na Wydziale Filozoficzno-Historycznym Uniwersytetu Jagiellońskiego. W pracy tej zaprezentował szeroką gamę problemów społecznych, oświatowych i kulturowych związanych z funkcjonowaniem polskiego szkolnictwa w trudnym powojennym okresie organizowania się życia społecznego.

Uzyskanie przez dr. Andrzeja Meissnera tytułu naukowego doktora habilitowanego umożliwiło powołanie do życia w Wyższej Szkole Pedagogicznej w Rzeszowie, w ra- 


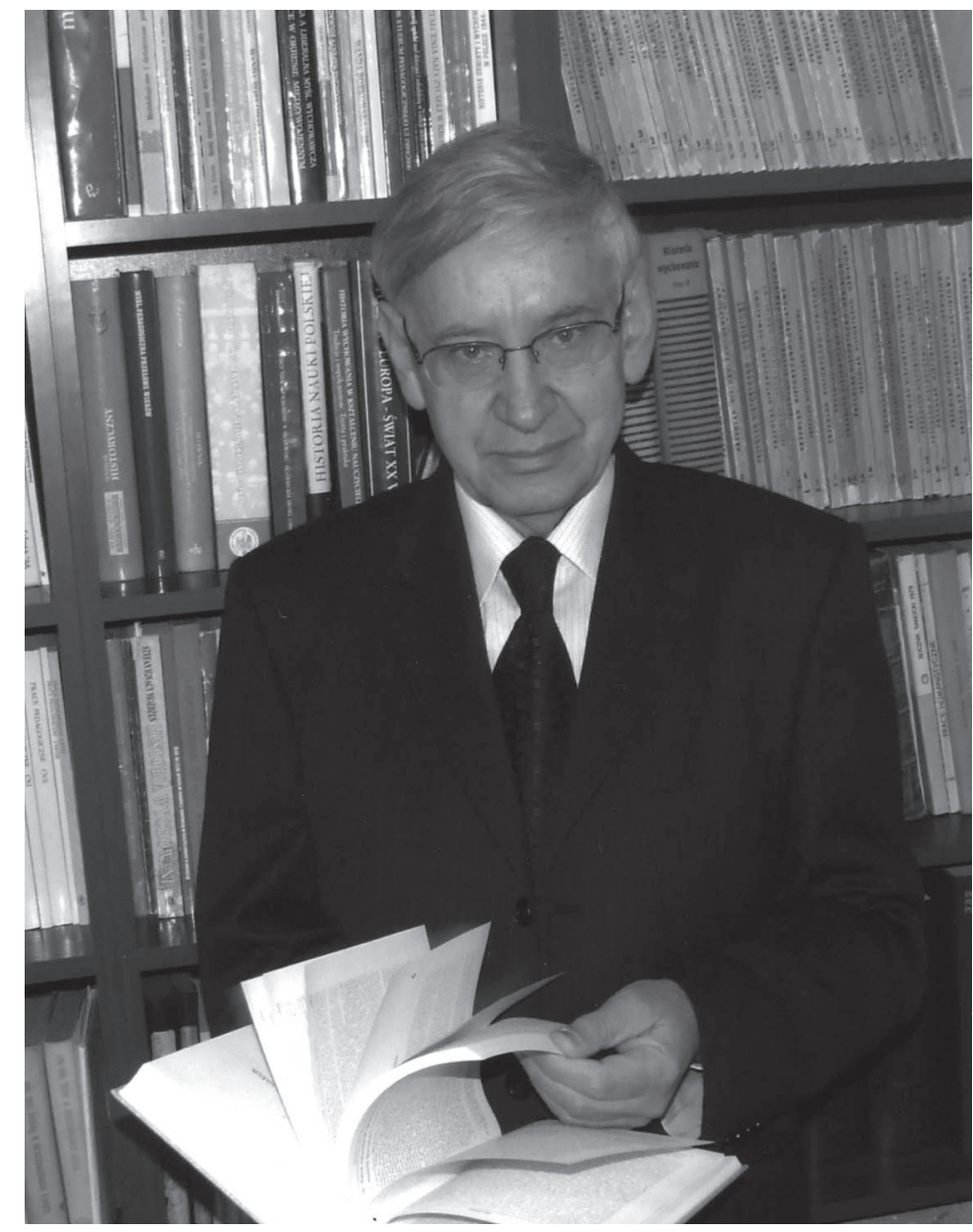

mach Instytutu Pedagogiki, Zakładu Historii Wychowania, co w istotny sposób wpłynęło na stopniowe kształtowanie się znaczącego ośrodka badań i studiów nad przeszłością edukacyjną i myślą pedagogiczną Galicji. W ciągu 45 lat pracy nauczycielskiej i akademickiej prof. A. Meissner przeszedł wszystkie szczeble drogi rozwoju naukowego, sięgając po godność profesora nauk humanistycznych (2001).

Głównym polem dokonań naukowo-badawczych prof. Andrzeja Meissnera pozostaje problematyka szkolnictwa i oświaty, myśli pedagogicznej i kultury umysłowej zaboru austriackiego, zwłaszcza Galicji doby autonomicznej. W Jego dorobku naukowym poświęconym Galicji, liczącym ponad 100 publikacji, uderza rozległość i różnorodność badań źródłowych, rzetelność faktograficzna i kompetentna prezentacja tła społeczno-oświatowego. Dzięki długotrwałym i pogłębionym badaniom w archiwach lwowskich prof. A. Meissner przyczynił się do wyjaśnienia, a często też do zasadniczej weryfikacji 
ocen o szkole i nauczycielu galicyjskim. Rzetelnie ukazywał ich rzeczywistą rolę w systemie oświaty galicyjskiej, podkreślił znaczenie ich umysłowego i społecznego wkładu dla postępu kultury i rozwoju cywilizacji na obszarze bardzo zaniedbanej prowincji monarchii austriackiej. Szczególnie zwrócił uwagę na liczne uwarunkowania rozwoju oświaty galicyjskiej, recepcji zachodnio-europejskiej praktyki i myśli oświatowej, a także na kształtowanie się rodzimej teorii i praktyki pedagogicznej.

Ważne miejsce w twórczości naukowej prof. A. Meissnera zajmuje biografistyka historyczno-pedagogiczna. W Jego dorobku znajdujemy około 260 biogramów i not biograficznych nauczycieli, działaczy oświatowych, przedstawicieli nauk pedagogicznych, historyków wychowania XIX i XX w., które opublikował w Polskim słowniku biograficznym (Warszawa- Kraków 1999, 2005, 2007); w Słowniku pedagogów polskich, (Katowice 1998); w Polskim słowniku biograficznym nauczycieli $w$ Małopolsce $w$ latach II wojny światowej (1939-1945), (Kraków1995); w Encyklopedii pedagogicznej XXI wieku, T. I-IV, (Warszawa 2003-2006) oraz w Stowniku biograficznym historii wychowania XIX i XX wieku (Toruń 2008).

Oddzielne miejsce w dorobku naukowym zajmują badania nad kształtowaniem się tożsamości historii wychowania jako nauki oraz rozważania nad historią wychowania jako przedmiotu edukacji nauczycielskiej. Należy tu wymienić rozprawy: Uźródet historii wychowania jako nauki, Wkład Galicji w rozwój historii wychowania, Środowisko historyków wychowania w XIX wieku, Polskie podręczniki do historii wychowania i inne. Autor opracowań uświadamia współczesnym decydentom odpowiedzialnym za kształt oświaty i system kształcenia nauczycieli, że historia wychowania to ważny przedmiot nauczania, który uczy rozumienia nowych prądów i dystansu do nowinkarstwa, walczy o rangę historii i jej miejsce w tworzeniu kultury pedagogicznej nauczycieli.

Począwszy od lat 70. współtworzył „Szkołę badań nad szkolnictwem i kulturą pedagogiczną Galicji doby autonomicznej”. Postawę badawczą łączył z otwartością i umiejętnością współpracy, dzięki temu włączył do preferowanej przez siebie problematyki badawczej swoich uczniów i współpracowników. Cechą tej „Szkoły” było podjęcie badań nad szeroko rozumianą oświatą pod zaborem austriackim, głównie opartą na archiwaliach lwowskich. Efekty tych badań uwieńczono kilkoma doktoratami, pracami habilitacyjnymi, opracowaniami zbiorowymi stanowiącymi pokłosie krajowych i międzynarodowych konferencji naukowych. Ich wyniki opublikowano głównie w serii wydawniczej „Galicja i jej dziedzictwo".

Profesor A. Meissner reprezentuje typ umysłowości otwartej na różne, coraz to nowsze zagadnienia badawcze, ale zakorzenione historycznie. Reprezentuje naukową postawę poszukującą prawdy historycznej w minionej rzeczywistości oświatowej i traktuje ją w perspektywie jej związków ze współczesnością. Posługuje się najczęściej metodologią nastawioną na poznanie istotnego szczegółu, a zgromadzoną warstwę faktograficzną poddaje wielostronnej analizie procesu historyczno-oświatowego. W postawie uczonego i nauczyciela pozostaje wierny sobie i jest konsekwentny wobec wcześniej przyjętych zasad postępowania naukowo-poznawczego i powinności pedagogicznej. W całej drodze działalności naukowej i akademickiej zachowuje stanowisko niezależności naukowej. 
Hołduje surowej ocenie porównawczej i weryfikacji badań naukowych. Podąża konsekwentnie własną drogą naukowego poznania i własnego stylu akademickiego.

W czerwcu 2008 r. przyjaciele i współpracownicy uroczyście wręczyli prof. Andrzejowi Meissnerowi księgę pamiątkową pt. Historia wychowania. Misja i edukacja, która ukazała się w serii „Galicja i jej dziedzictwo” (Rzeszów, t. 20). W części wstępnej publikacji wiele miejsca poświęcono sylwetce Jubilata wraz z wykazem publikacji naukowych. Kazimierz Szmyd w szkicu Andrzej Meissner, historyk wychowania i oświaty, uczony $i$ nauczyciel dobitnie wyeksponował działalność Jubilata na rzecz organizowania w Uniwersytecie Rzeszowskim mocnego ośrodka badań historyczno-pedagogicznych, zajmującego ważne miejsce na mapie naukowej Polski. Zasadnicza część wydawnictwa zawiera artykuły i rozprawy dedykowane Jubilatowi, które obejmują kilka kręgów tematycznych m.in.: „Szkoła i jej wpływ na przemiany cywilizacyjne”, „Miejsce szkolnictwa w kształceniu kadr”, „Edukacja etniczna i wielokulturowa”, „Opieka nad dzieckiem i oświata dorosłych”, „Między tradycją a współczesnością”. Wszystkie te części wiąże wspólna idea ukazania oświaty jako czynnika odgrywającego istotną rolę w przemianach cywilizacyjnych Galicji, która na przełomie XIX i XX stulecia powoli przekształcała się w bardziej nowoczesny kraj koronny monarchii austro-węgierskiej.

W zakończeniu krótkiej i pobieżnej charakterystyki działalności Profesora Meissnera warto zwrócić uwagę na Jego cechy charakteru, tj.: życzliwość w działaniu, powściągliwość w słowach, tolerancję, a przede wszystkim unikanie emocjonalnych opinii. Należy On do tych uczonych, który chętnie inicjuje badania naukowe, służy młodzieży, pomaga młodym uczonym z różnych ośrodków naukowych. Służy radą i pomocą przy organizowaniu konferencji naukowych, recenzowaniu prac doktorskich i habilitacyjnych, a także imponuje swą erudycją naukową. Za wieloletnią wytężoną pracę i odpowiedzialną postawę uczonego i nauczyciela akademickiego Profesor otrzymał liczne odznaczenia państwowe, medale, wyróżnienia i nagrody.

Jako jego współpracownicy i przyjaciele żywimy głębokie przekonanie, że jest to znaczący etap, ale też i cząstka Jego długich jeszcze lat życia, aktywności naukowej i zawodowej. Życzymy Panu Profesorowi dużo zdrowia i sił do pomnażania dorobku polskiej historii i myśli pedagogicznej. 